\title{
Forest Cover Dynamics Detection in Lume District, Oromia Region, Central Ethiopia
}

\author{
Hailu Wondu \\ Department of Forest and Range Land Plant Biodiversity, Ethiopian Biodiversity Institute, Addis Ababa, Ethiopia \\ Email address: \\ Hailuwon2@gmail.com \\ To cite this article: \\ Hailu Wondu. Forest Cover Dynamics Detection in Lume District, Oromia Region, Central Ethiopia. International Journal of Environmental \\ Monitoring and Analysis. Vol. 9, No. 1, 2021, pp. 11-20. doi: 10.11648/j.ijema.20210901.12
}

Received: October 12, 2020; Accepted: November 2, 2020; Published: March 10, 2021

\begin{abstract}
Forest cover dynamics is a critical global problem that affects the socio-economic and ecological function of forest landscape in the globe The Earth's forest cover is continuously altered by several climatological and anthropogenic factors. And its change influence world carbon cycle and biodiversity pool at local, regional and global scale. Lume district in Ethiopia is one of potential area that has important socio-economic and ecological function. Currently, despite their contribution to both economic and ecological services forests of Lume district are under serious streak both from anthropogenic and natural calamities. Hence, the fundamental aim of this study is to investigate the magnitude, trend and rate of forest cover change for the last 33 years (1985-2018). Quantitative data was collected using Landsat5 TM and Landsat8 OLI_TIRS satellite image, which used to define the spatial and temporal changes. SCP, QGIS 2.18.2, MOLUSCE and EXCEL were used for processing and analyzing data obtained from satellite image (https://earthexplorer.usgs.gov/). Four period Landsat image data of 1985, 1999, 2013 and 2018 were used to produce land cover map in general and forest cover map in particular. The finding of the study depicted that, during 33 years period agriculture land and urban building increased by 728ha $(10.82 \%)$, 1547.92ha $(21.39 \%)$ respectively with equivalent decline of 3887 ha $(5.37 \%)$ forestland and 17502.55 ha $(24.2 \%)$ shrub land. Throughout the study periods, steady net increasing rate of expansions observed for urban buildings and agriculture land by 468.8 ha and 237.27ha/annual, whereas, a net decline rate noted for scrublands and forests by 530.38 ha and $117.8 \mathrm{ha} /$ year. The main findings of this study disclosed that, a resume increase in agriculture land and urban buildings and settlements at the expense of forests and shrub lands throughout investigated periods. Hence, in order to revoke the problem of forest cover change and its impact, proper measures had been forwarded which can be implemented both in the long and shortterm commitment of anxious stakeholders in the district and national level.
\end{abstract}

Keywords: Remote Sensing, Accuracy, Geographic Information System, Molusce, Satellite Image

\section{Introduction}

Forests make up one of the world's most important precious natural resource and play a crucial role in global ecological balance. The forests of the world cover about 4 billion hectares. Forests provide support for one billion people that live in far beyond the norm poverty around the world, and provide emolumentive employment to more than one hundred million. In Africa forests are very crucial for protecting water catchments and for enhancing conservation; for regulating rainfall; for preventing landslides and are an in important of biodiversity pool [1].

In Ethiopia, Forest-based ecosystem services are directly available as products derived from and within forests and those that indirectly support other production landscapes. According to MOFED, forestry sector contributed on average $5.7 \%$ of the total GDP in Ethiopia over the years 1995-2005. Despite their significant pertaining to both economic and ecological services, forests are currently under serious threats both from anthropogenic and natural destructives. Globally, there is a decline in forest cover from $31.6 \%$ to $30.6 \%$ [2]. Deforestation is most noticeable in tropical regions such as Africa. Africa accounted for a net loss of 4.0 million hectares per year. In East Africa, forests and woodlands making these resources quite limited and threatened cover around only $13 \%$ of the land mass [3]. Ethiopia is part of the dynamic land cover change where more than $90 \%$ of 
the country's highlands once forested, and currently the percentage of forest cover is less than $12 \%$ [4].

Due to massive exploitation, the forest resource of the country has marginalized itself to small remnants on the highlands particularly, almost all located at unreachable areas. However, there is information deficit associated to extent of forest cover, location, rate of expedition and documentation of relevant information about the remaining forest cover of the country. Similarly, in the study area, Lume district, there is high forest cover change due to agricultural expansion, energy production (fuel wood and charcoal), settlement, the establishment of infrastructure such as road; industries and urbanization also contribute for forest cover change. However, the rate and an actual extent of the forest cover change has not well studied to date. Thus, for a sustainable forest management, to assess and monitor the trends of forest cover change and the drivers; it is necessary to estimate forest cover change on large spatial and temporal scales. The overall aim of this study is to investigate the long-term magnitude, rate and trends of forest cover change in the district.

\section{Method}

The study had conducted in Lume district, Oromia Region, East Shoa Zone, Ethiopia. The geographical extent of the district lies between $8^{\circ} 38^{\prime} 42^{\prime \prime} \mathrm{N}$ and $39^{\circ} 14^{\prime} 32^{\prime \prime} \mathrm{E}$. The altitude of the area ranges from 1500 to 2300 meters above sea level. Areal coverage is about $151 \mathrm{~km}^{2}$ and located at $70 \mathrm{~km}$ southeast of Addis Ababa.

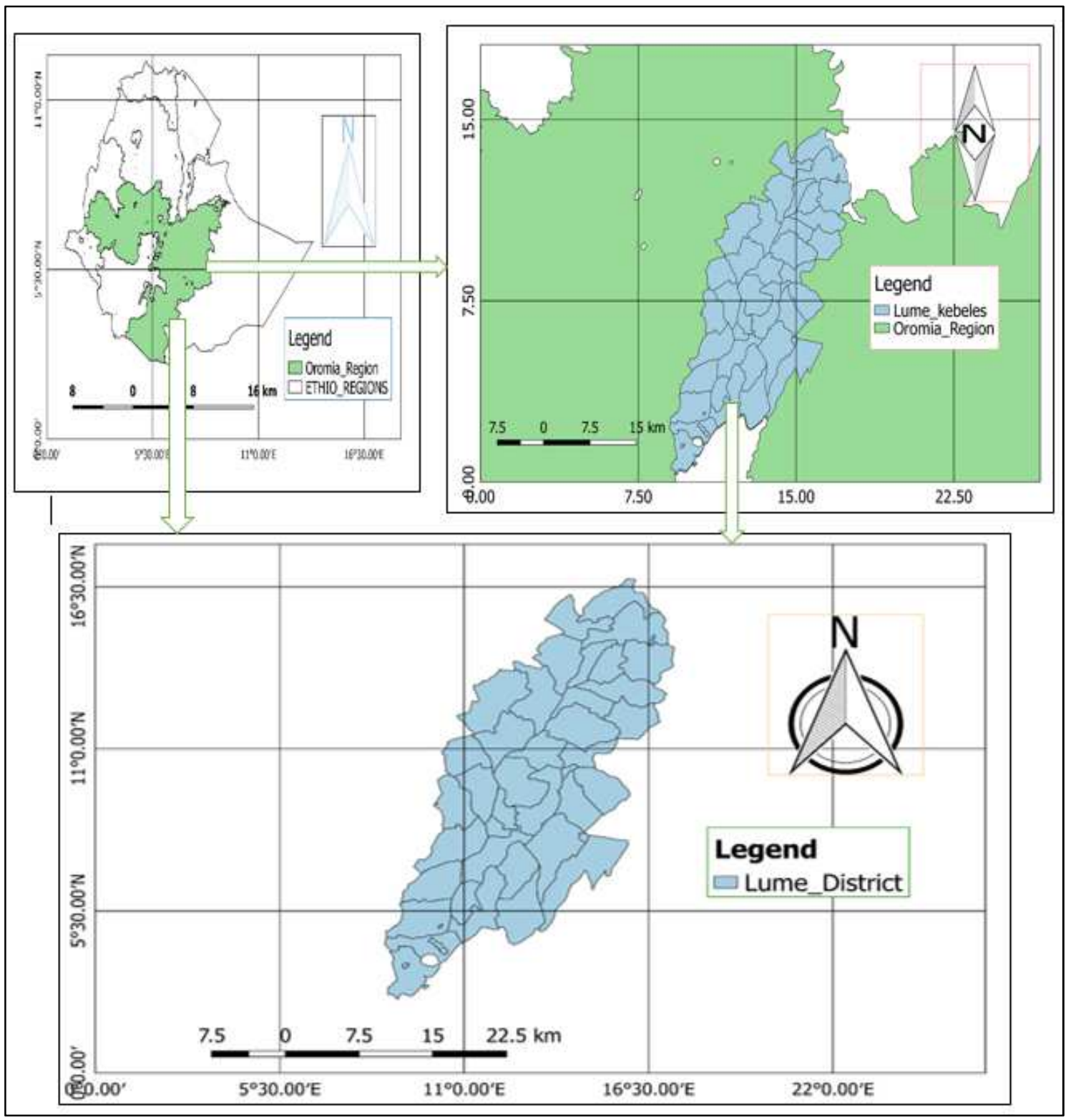

Figure 1. Map of study area.

Both primary and secondary data have been employed in this research, which enabled to produce sound finding and objective based results. Four (4) period primary satellite image data were used in this research. Landsat5 TM 
acquisition date on 1985/01/02 and 1999/01/25, Landsat8 OLI_TIRS acquisition date on 2013/12/01 and 2018/02/01. This satellite image data were used for change detection of two consecutive period. Landsat7 ETM+ was not used for satellite data since it was full of strip and blurred to distinguish spectral value of various landscape. Time interval between the first two periods was 14 years, whereas 5 years for the last period since there was no Landsat5 and Landsat8 images from 2000-2010.

The image pre-processing tasks were carried out in semiAutomatic Classification Plugin (SCP) for area of interest (AOI). Image pre-processing involves manipulation and interpretation of digital imageries. Spatial resolution of images were enhanced using resolution merge technique, which integrated images of different spatial resolution or pixel sizes. Furthermore, radiometric enhancement was used to improve the area of image by addressing stripping and banding errors that occur when the detector goes out of adjustment. Each image was assigned to be classified into seven (7) land classes based on specific Digital Number (DN) values or spectral reflectance of different landscape elements. Maximum likelihood algorithm employed for supervised classification of images. The Region of interest (ROI) applied for producing the map by defining an area in the image based on the colour assign to that category and spectral homogeneity of pixels of chosen area [5]. After classification, ground verification were done in order to check the precision of classified LU/LC (forest cover) map.

Following classification and verification, reclassification was proceed to classify land cover categories into forest and non-forestland cover. The reclassified images were then compared to determine the change that has taken place between two images using a change matrix. The map from $t_{1}$ (1985) was computed with map produced at $t_{2}$ (1999) as well as the map at $t_{2}$ was compared with the map produced at $t_{3}$ (2013), whereas the map at $t_{3}$ was reckoned with the map at $\mathrm{t}_{4}$ (2018). Eventually a complete matrix of categorical change was obtained using MOLUSCE software in QGIS. For this study, the following formulas were employed in change detection process:

$$
\begin{gathered}
\mathrm{K}=(Q 2-Q 1) \\
\mathrm{A}=\frac{Q 2-Q 1}{Q 1} \\
\mathrm{R}=\frac{Q 2-Q 1}{t}
\end{gathered}
$$

Where, Q2 = recent year forest cover in ha, Q1= initial year forest cover in ha, $K=$ magnitude of change, $\mathrm{A}=$ Percentage of change and $\mathrm{t}=$ interval year between initial and recent year. For accuracy assessment, maximum number of validation point were randomly distributed on both supervised classification and historical image, which shows the ground truth of each land classes clearly. In addition, 372 ground control points had collected from each land classes, where $60 \%$ used for classification and $40 \%$ for accuracy assessment [6]. The accuracy assessment has done by a confusion matrix that delivers the relationship between samples taken as reference data and the corresponding samples on classified image. A minimum of $85 \%$ accurate classification at the $95 \%$ confidence level was recommended for this research. In this study, all accuracy assessment parameters (i.e. overall accuracy, producer's accuracy and user's accuracy) have determined for classified images of each year. More complete measure of classification accuracy called Kappa coefficient also included in the assessment. Minimum value of kappa hat between 0.61 and 0.80 was recommended for this research, which is substantial [7].

To improve the interpretability of the images, appropriate pre-processing including radiometric correction were applied by using Semi-Automatic Plugin of QGIS. After classification and reclassification, distribution of validation point proceeded from the ground truth on the maps randomly and coded as 1-7 for LU/LC in the attribute table. Then, this coded data were feeds to accuracy software in QGIS to produce error matrix table. Using MOLUSCE from QGIS, a real change and changed map were obtained for two consecutive years. Thus, areas that were converted from one class to any of other classes was computed and the directions were determined. The values had been computed in terms hectares and percentages.

\section{Result and Discussions}

\subsection{Investigating Magnitude and Patterns of Forest Cover Change}

Conducting LU/LC assessment in the study area result in identification of 7 land use classes: agriculture land, urban building, scrubland, woodlot, lake, bare land and forestland. The result showed that, rapid increments of urban buildings and agricultural land in the last 33 years investigation. In contrary, shrub land and forest land have highly declined. In between 1999 to 2013 and 2013 and 2018 agriculture land has shown increment in $8.33 \%$ and $2.76 \%$ respectively. Reversely, forestland has shown decline to $-0.37 \%$ and $-0.3 \%$ respectively, it might be due to conversion into cultivation, which has lead agricultural land expansion at its expense. This report in line with suggested that, the land use and land cover changes that were detected in all study areas revealed, in general, the greater areas of wood land, shrub land and grazing land were transformed into agricultural land, bare land and settlement [8].

In the years between 1985-1999 and 2013-2018 there was significant shrub land area reduction 12275.74 and 5519.21 ha respectively, which has directly converted to agricultural land and settlements and/or urban buildings Similar result also reported as, over the entire study period, the annual rate of the cropland area increased. While the rate of the woodland and shrub/bush land, area declined and showed a fluctuating trend between the study years [9]. Throughout the study periods agriculture land indicate an increasing tendency of $13.38 \%, 22.92 \%, 24.1 \%$ and $30.06 \%$ 
respectively that might be due to settlement area expansion for the sake of high rate of population growth and infrastructural development due to urbanization (Figure 2, Figure 3, Figure 4, Figure 5 and Table 1). These reports in line with the finding, which noted, rapidly growing of population brought shortage of land, removal of forest cover and soil erosion and land degradation [10]. The finding also agreed with statement, as the increased population has also meant more demand for food items and hence more pressure to clear forestland to provide for the demanded food [11].

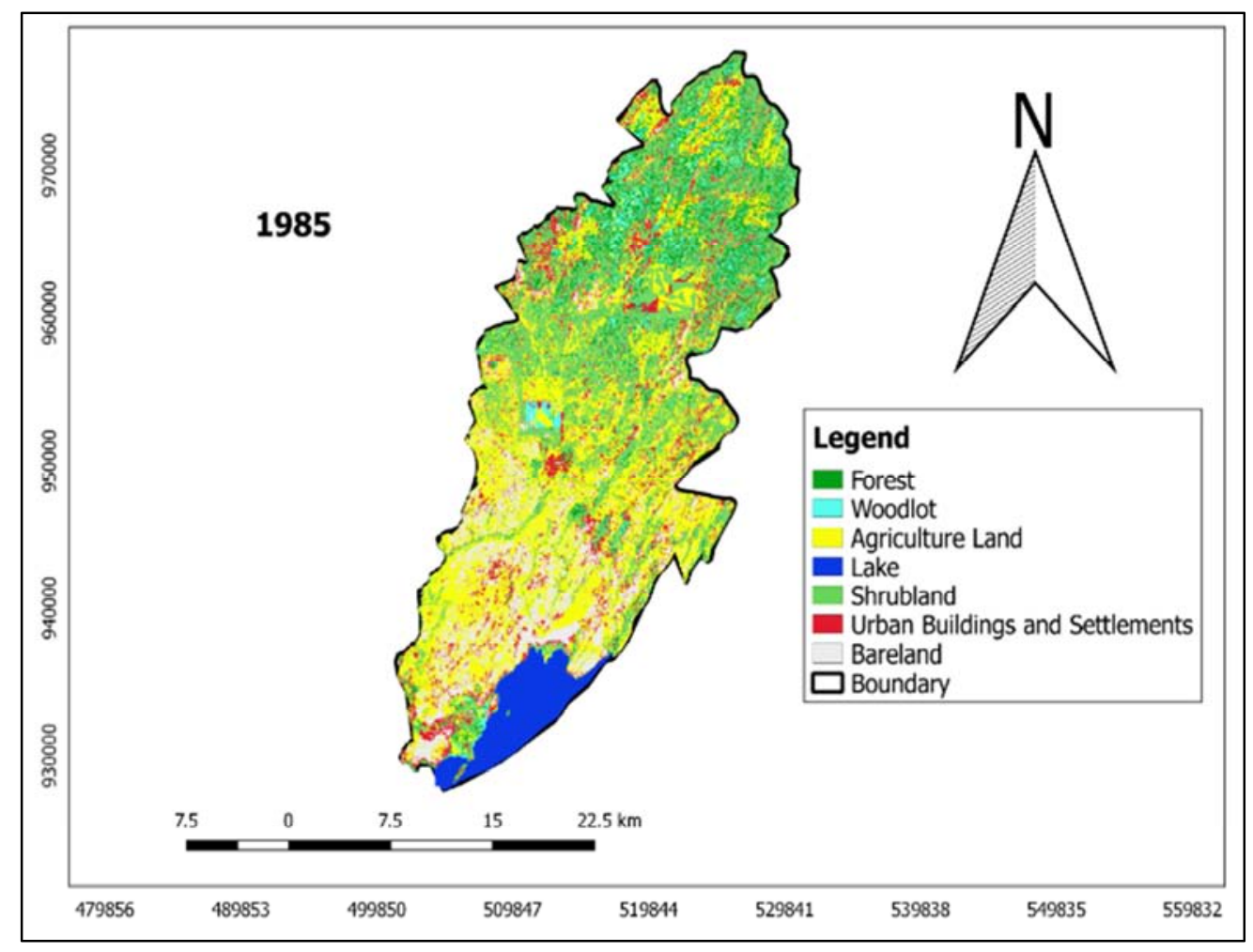

Figure 2. Map of LUCL in 1985.

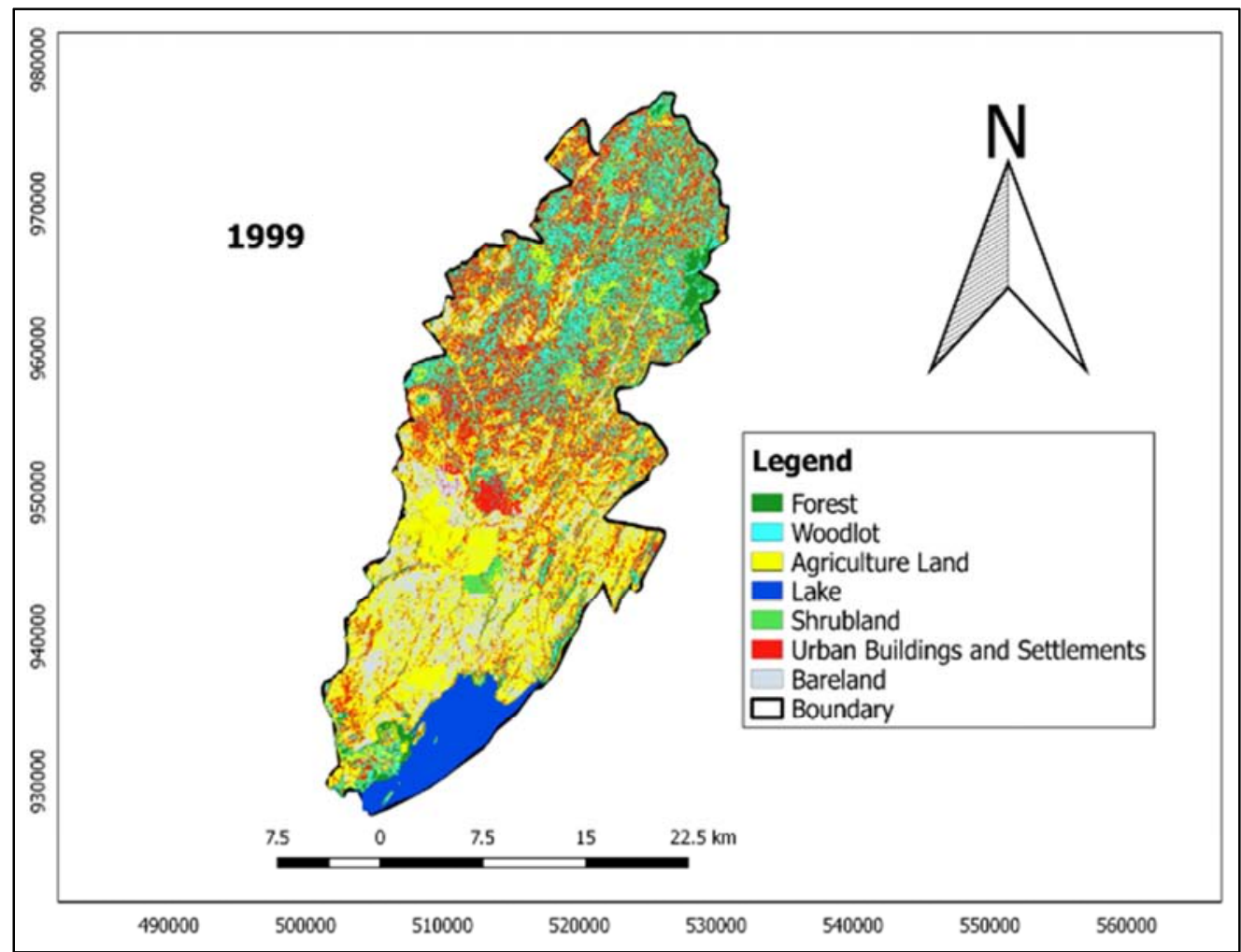

Figure 3. Map of LULC in 1999. 


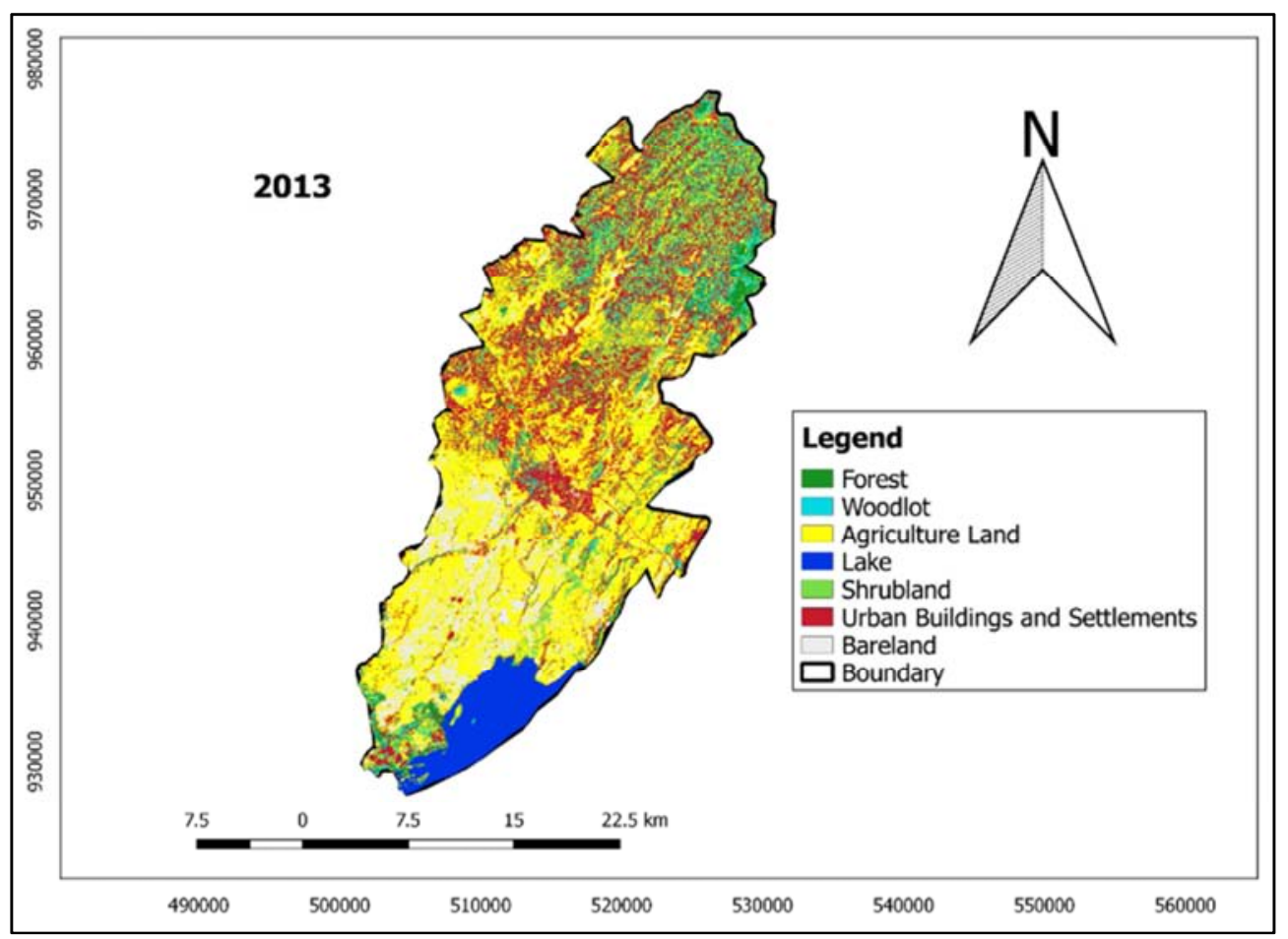

Figure 4. Map of LULC in 2013.

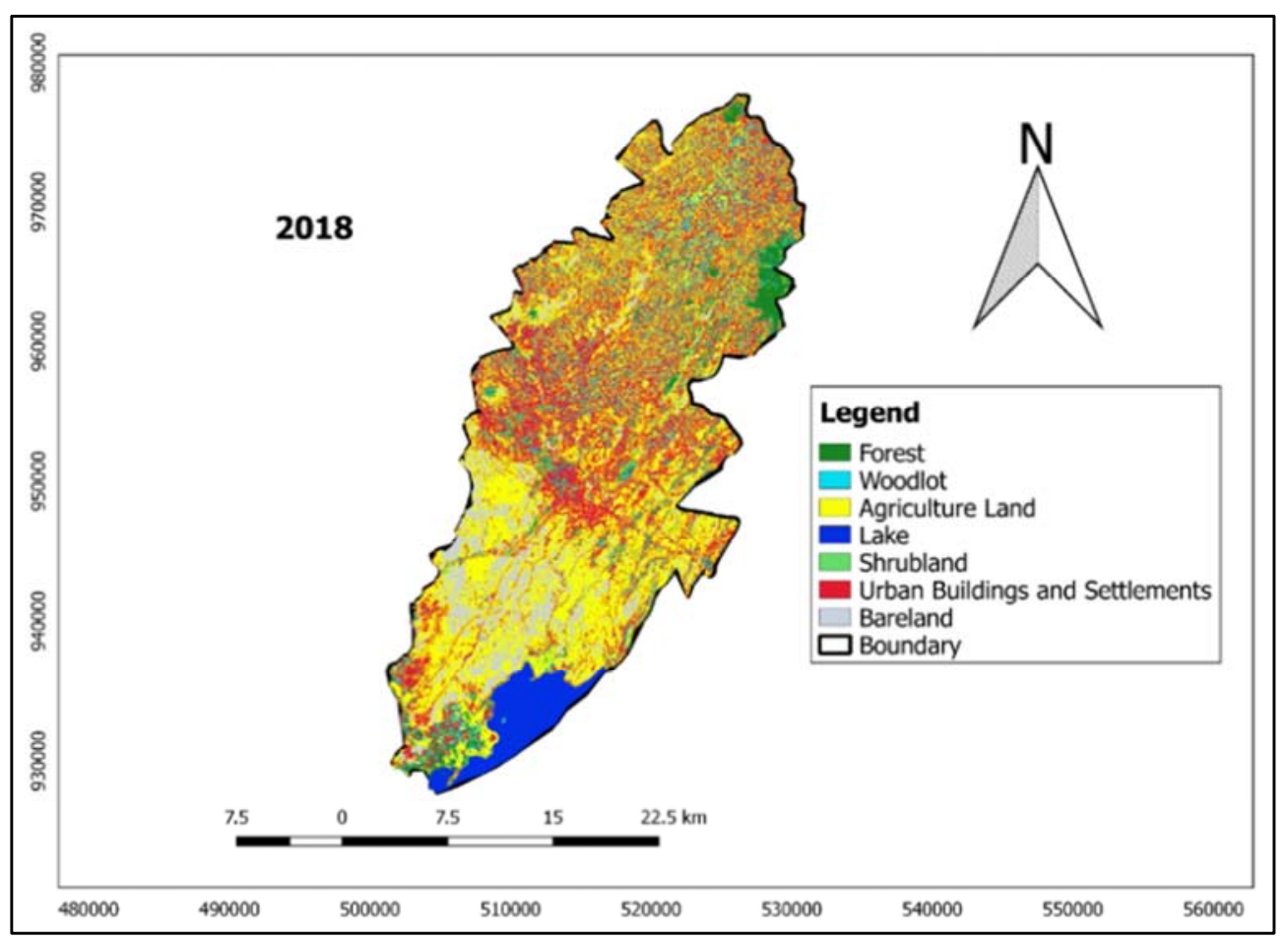

Figure 5. Map of LULC in 2018.

Agriculture land declines only in the period between 1985 and 1999 by $-0.27 \%$ that could be converted to settlement area due to resettlement program of the dergue policy following 1984/5 famine. In the year between 1985 and 1999, forestland declined by $-3401.71 \mathrm{ha}(-4.7 \%)$ and shrubland reduced by $-12275.74 \mathrm{ha}(-16.97 \%)$ whereas woodlot and settlement area increased by $6.42 \%$ and $14.24 \%$ respectively, there was high rate of deforestation during this period since it was transition period (1990-1991) for the downfall of dergue regime, political unrest and the coming of current government. Similar reports in statement of which, the majority of these 'community forests' were destroyed during the conflict and transition after the downfall of the Dergue (1991) because they were undertaken without the consent of the locals with the exception of the few cases [12].

The result depicted from the year 1985 to 2018 there has 
been a net gain for woodlot, agriculture land, and urban buildings and/or settlements by 1369.11 ha, 7828.73 ha and 15471.92ha consecutively, in contrary, there has been a net loss for forest land, shrub land, lake and bare land by 3887ha, -17502.55ha and -2690.69ha (Table 2). This could be due to the increasing demand for land in expansion of agricultural land and space for settlements and buildings including bare land/ open space with relevant rapid rate of population growth. The net gain from woodlot might be due to the increasing demand of tree planting around home for fuelwood consumption with respective expansion of settlement area.

Table 1. Patterns of LULC 1985-2018.

\begin{tabular}{|c|c|c|c|c|c|c|c|c|}
\hline \multirow{2}{*}{ Land Cover classes } & \multicolumn{2}{|l|}{1985} & \multicolumn{2}{|l|}{1999} & \multicolumn{2}{|l|}{2013} & \multicolumn{2}{|l|}{2018} \\
\hline & Area (ha) & $\%$ & Area (ha) & $\%$ & Area (ha) & $\%$ & Area (ha) & $\%$ \\
\hline Forest & 6779.3 & 9.37 & 3377.59 & 4.67 & 3107.24 & 4.29 & 2891.45 & 3.99 \\
\hline Woodlot & 3663.69 & 5.06 & 8306.5 & 11.48 & 3223.55 & 4.45 & 5032.8 & 6.96 \\
\hline Agriculture Land & 20588.36 & 28.46 & 20392.91 & 28.19 & 26418.07 & 36.52 & 28417.09 & 39.28 \\
\hline Lake & 3876.69 & 5.36 & 4110.76 & 5.68 & 4227.43 & 5.84 & 3288.01 & 4.54 \\
\hline Shrub land & 21477 & 29.69 & 9201.27 & 12.72 & 9493.67 & 13.12 & 3974.46 & 5.49 \\
\hline Urban Buildings and Settlements & 6275.79 & 13.38 & 16580.77 & 22.92 & 17511.45 & 24.21 & 21747.71 & 30.06 \\
\hline
\end{tabular}

Table 1. Magnitude of LULC 1985-2108.

\begin{tabular}{|c|c|c|c|c|c|c|c|c|}
\hline \multirow[b]{2}{*}{ Land cover classes } & \multicolumn{2}{|l|}{ 1985-1999 } & \multicolumn{2}{|l|}{ 1999-2013 } & \multicolumn{2}{|l|}{ 2013-2018 } & \multicolumn{2}{|l|}{ 1985-2018 } \\
\hline & $\begin{array}{l}\Delta \text { Area } \\
\text { (ha) }\end{array}$ & $\Delta \%$ & $\Delta$ Area (ha) & $\Delta \%$ & $\Delta$ Area (ha) & $\Delta \%$ & $\begin{array}{l}\text { Net } \Delta \text { Area } \\
\text { (ha) }\end{array}$ & Net $\Delta \%$ \\
\hline Forests & -3401.71 & -4.7 & -270.35 & -0.37 & -215.79 & -0.3 & -3887.85 & -5.37 \\
\hline Woodlot & 4642.81 & 6.42 & -5082.95 & -7.03 & 1809.25 & 2.5 & 1369.11 & 1.89 \\
\hline Agriculture Land & -195.45 & -0.27 & 6025.16 & 8.33 & 1999.02 & 2.76 & 7828.73 & 10.82 \\
\hline Lake & 234.07 & 0.32 & 116.67 & 0.16 & -939.42 & -1.3 & 588.68 & -0.82 \\
\hline Shu bland & -12275.74 & -16.97 & 292.4 & 0.4 & -5519.21 & -7.63 & -17502.55 & -24.2 \\
\hline Urban Buildings and Settlements & 10304.98 & 14.24 & 930.69 & 1.29 & 4236.25 & 5.86 & 15471.92 & 21.39 \\
\hline Bare land & 691.04 & 0.95 & -2011.63 & -2.78 & -1370.1 & -1.89 & -2690.69 & -3.72 \\
\hline
\end{tabular}

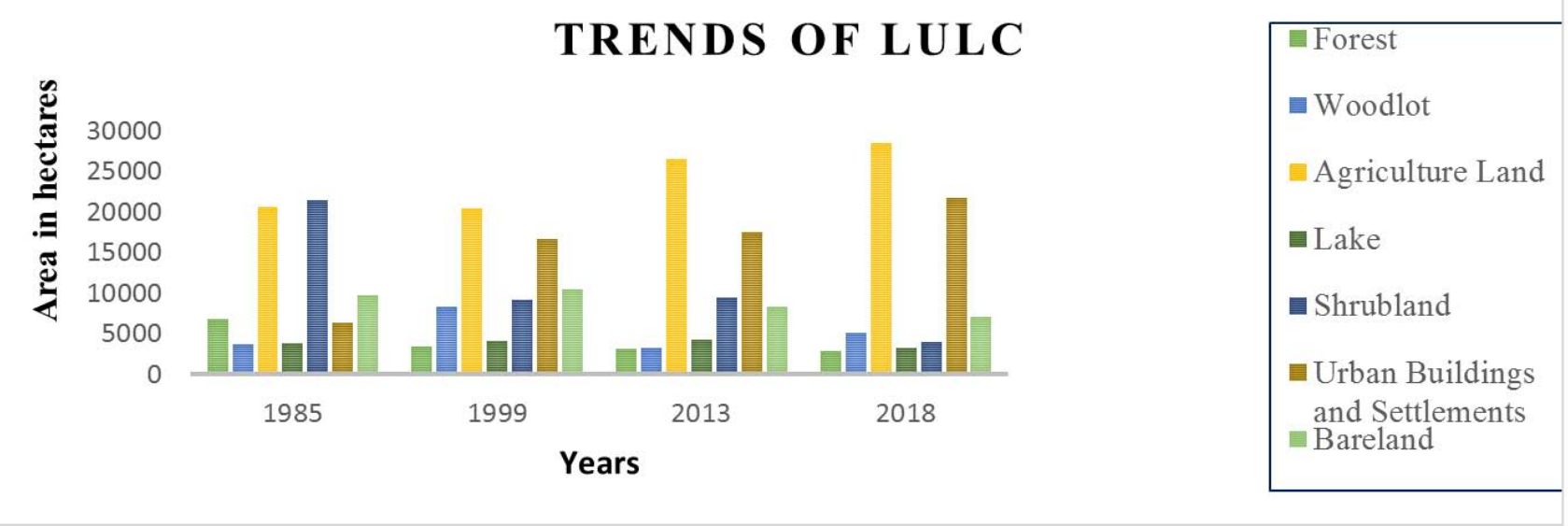

Figure 6. Land Use /Land Cover patterns of Lume district from 1985-2018.

\subsection{Examining Extent and Rate of Forest Cover Change (1985-2018)}

In the year between 1985 and 1999, forestland declined by -3401.71 ha $(-4.7 \%)$ and shrub land reduced by -12275.74 ha $(-16.97 \%)$ whereas woodlot and settlement area increased by $6.42 \%$ and $14.24 \%$ respectively. This insists that forestland and shrub land decreased at the rate of $243 \mathrm{ha}$ and $876 \mathrm{ha}$ per year respectively, while woodlot and settlement area increased by rate of $331.63 \mathrm{ha}$ and $736 \mathrm{ha}$ per annum consecutively. This finding confirmed the result which depicted that, rate of forest cover change from year 1973 to 1986 is -245.2 ha per year (6044.4ha -2855.9 ha/13 years) and from year 1986 to 2003 , it was -24 ha annually (2855.9$2446.9 \mathrm{ha} / 17$ years) [13]. In the second and third period also the declined of forest and shrub land cover continued by rate of 19.31ha, 43.2ha and 20.88ha, 1103.84ha per annum consecutively, whereas the area devoted for agriculture land and urban buildings and settlements keep on steady expansion in the remaining periods (1999-2013 and 20132018 ) by the rate 430.4 ha, 399.8 ha and 66.5 ha, 847.25 ha per year respectively (Table 3 ). It might be due to high demand for food crop production and space for buildings and settlements with corresponding high rate of population growth. The finding depicted that the average rate of forest cover change in the interval of 1985 and 1999 was declined by 19.3 ha per annum whereas, between 2013 and 2018 
decreased by 43.16ha per year. The annual rate of forest cover change though investigation period was -117.8 ha. This could due to alarming rate of population growth in needs for high food security and space for settlements combined with low income source forced farmers and residents to deforestation.

The result indicated that the extent of areal share of forest lands from the total land cover of the district which implies maximum share in 1985 of which 6779.3 ha $(9.37 \%)$ and minimum share in 2018 of which 2891.45ha (4\%). In between 1985 and 1999 high amount of forestland 3401.71ha $(4.7 \%)$ was converted to non-forestlands and in between 2013 and 2018 relatively low amount forest area 215.79ha $(0.3 \%)$ was converted to non-forestland. This might be due to participatory forest management become formally recognized in forest proclamations of Ethiopia's Federal Government and several regional states, which in turn increases ownership and responsibilities of local communities towards forest conservation.

The change happened in the district were reduce forestland and shrub land due to deforestation, Agricultural land expansion, expansion of settlements and urban buildings were the major changes encountered in the assessment period. Urban buildings and settlements undergoes the most increment change during the study period. Hence the area coverage of urban buildings and settlements 6275.79ha $(13.38 \%)$ in 1985 increased to 21747.71 ha $(30.06 \%)$ in 2018 , which was a dramatic change from LULC existed in the district and followed by agricultural land which covers 20588.36ha (28.46\%) in 1985 and 28417.09ha (39.28\%) in 2018. Forestland cover indicate a negative change over the 33 year settlement experienced a most positive change over the 33-year study period. This might be, as result of ongoing population growth, socio economic activities for livelihood, urbanization and technological transformation. Similarly [14] stated that, the increase of aerial coverage for cropland and grassland was due to an increase of population pressure, demand for cultivated land and intervention of soil conservation practice by different NGOs and Governmental.



Figure 7. Changed map of Lume District between 1985 Ind 2018

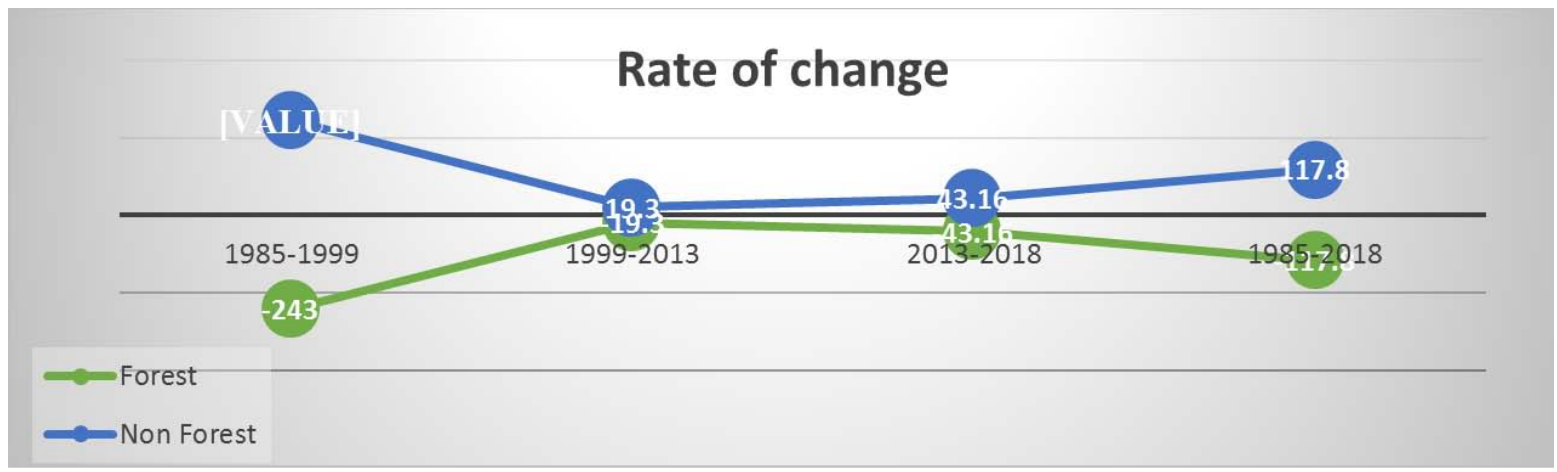

Figure 8. Rate of Forest cover change in Lume district (1985-2018). 
Table 3. Rate of Land Use/ Land Cover Change (1985-2018).

\begin{tabular}{|c|c|c|c|c|c|c|c|c|}
\hline \multirow[b]{2}{*}{ Land Cover classes } & \multicolumn{2}{|l|}{ 1985-1999 } & \multicolumn{2}{|l|}{ 1999-2013 } & \multicolumn{2}{|l|}{ 2013-2018 } & \multicolumn{2}{|l|}{ 1985-2018 } \\
\hline & $\begin{array}{l}\% \text { age of } \Delta \\
\text { (A) }\end{array}$ & $\begin{array}{l}\text { rate of } \Delta \\
\text { (r) }\end{array}$ & $\begin{array}{l}\% \text { age of } \Delta \\
\text { (A) }\end{array}$ & $\begin{array}{l}\text { rate of } \Delta \\
\text { (r) }\end{array}$ & $\begin{array}{l}\% \text { age of } \Delta \\
\text { (A) }\end{array}$ & $\begin{array}{l}\text { rate of } \Delta \\
\text { (r) }\end{array}$ & $\begin{array}{l}\% \text { age of } \Delta \\
\text { (A) }\end{array}$ & $\begin{array}{l}\text { rate of } \Delta \\
\text { (r) }\end{array}$ \\
\hline Forests & -0.5 & -243 & -0.08 & -19.31 & -0.07 & -43.2 & -0.57 & -117.8 \\
\hline Woodlot & 1.3 & 331.63 & -0.61 & -25.93 & 0.56 & 361.85 & 0.37 & 41.48 \\
\hline Agriculture Land & -0.009 & -13.96 & 0.3 & 430.4 & 0.75 & 399.8 & 0.38 & 237.23 \\
\hline Lake & 0.06 & 16.72 & 0.03 & 8.33 & -0.22 & -187.88 & -0.15 & -17.84 \\
\hline Shrub land & -0.57 & -876.84 & 0.03 & 20.88 & -0.58 & 1103.84 & -0.81 & -530.38 \\
\hline Urban Buildings and Settlements & 1.64 & 736 & 0.05 & 66.5 & 0.24 & 847.25 & 2.46 & 468.8 \\
\hline Bare land & 0.07 & 49.36 & -0.19 & -143.69 & -0.16 & -538 & -0.28 & -81.5 \\
\hline
\end{tabular}

\subsection{Accuracy Assessment for Classified Images of 1985-2018}

Accuracy assessment is an important step in the process of analysing remote sensing data. Remote sensing products can used as the basis for political as well as economical decisions. Potential users have to know about the reliability of the data when face up with maps derived from remote sensing data. In order to increase the result of overall accuracy, images of different land use/land cover divided into more parts. For instance, in this study agricultural land divided into five different parts to increase homogeneity of pixels and finally categorize as agricultural land. Thus, $86.16 \%, 84.7 \%, 85.8 \%$ and $85 \%$ overall accuracy were achieved for 1985, 1999, 2013 and 2018 respectively, which is satisfactory level for GIS and RS research.

Table 4. Confusion matrix of 1985 LULC classification.

\begin{tabular}{|c|c|c|c|c|c|c|c|c|c|}
\hline \multirow{2}{*}{ Classification Data } & \multicolumn{8}{|c|}{ References Data } & \multirow{2}{*}{$\begin{array}{l}\text { User's } \\
\text { accuracy }\end{array}$} \\
\hline & Forest & Woodlot & Agriculture Land & Shrubland & Lake & Urban Buildings & Bare land & Total & \\
\hline Forest & 258 & 32 & 47 & 1 & 61 & 0 & 3 & 302 & $85.4 \%$ \\
\hline Woodlot & 65 & 107 & 39 & 3 & 12 & 0 & 0 & 176 & $60.8 \%$ \\
\hline Agriculture Land & 45 & 24 & 1460 & 3 & 168 & 36 & 105 & 1541 & $94.7 \%$ \\
\hline Lake & 0 & 0 & 0 & 253 & 0 & 0 & 0 & 253 & $100 \%$ \\
\hline Shrubland & 41 & 16 & 226 & 6 & 769 & 24 & 9 & 897 & $85.7 \%$ \\
\hline Urban Buildings & 6 & 3 & 85 & 5 & 26 & 157 & 37 & 249 & $63.1 \%$ \\
\hline Bare land & 3 & 2 & 121 & 0 & 10 & 37 & 459 & 531 & $86.4 \%$ \\
\hline Total & 318 & 134 & 1684 & 296 & 849 & 184 & 503 & 4019 & \\
\hline Producer's accuracy & $81.1 \%$ & $79.8 \%$ & $86.7 \%$ & $85.50 \%$ & $90.6 \%$ & $85.32 \%$ & $91.2 \%$ & & \\
\hline
\end{tabular}

Overall accuracy $=86.16 \%$

Kappa coefficient $=75.6 \%$

Furthermore, 0.756, 0.807, 0.787 and 0.779 kappa coefficient were attained for 1985, 1999, 2013 and 2018 consecutively, which is substantial agreement, that produced by accuracy assessment of error matrix/confusion matrix (Tables 4, 5, 6 and 7). The overall map accuracy is not always representative of the accuracy of individual classes. Therefore, both producer's and user's accuracy for all single classes need to be considered. For instance a higher user's accuracy (85.4\%) and low producer accuracy (81.1\%) implies that more forest loss in the map was also loss in the reference data (Table 4). In contrast to the overall accuracy, the Kappa coefficient considers also non-diagonal elements. This result confirmed the fact in other study, which noted that, A non-parametric Kappa test was used to measure the classification accuracy as it accounts for all the elements in the confusion matrix rather than the diagonal elements [15]. It measures the proportion of agreement after chance agreements have been removed from considerations. Therefore, always the value of kappa coefficient is less than overall accuracy.

Table 5. Confusion matrix of 1999 LULC classification.

\begin{tabular}{|c|c|c|c|c|c|c|c|c|c|}
\hline \multirow{2}{*}{ Classification Data } & \multicolumn{8}{|c|}{ Reference Data } & \multirow{2}{*}{$\begin{array}{l}\text { User's } \\
\text { accuracy }\end{array}$} \\
\hline & Forest & Woodlot & Agriculture Land & Lake & Shrubland & Urban buildings & Bare land & Total & \\
\hline Forest & 53 & 3 & 8 & 4 & 15 & 10 & 0 & 69 & $76.8 \%$ \\
\hline Woodlot & 21 & 257 & 35 & 4 & 45 & 39 & 0 & 311 & $82.6 \%$ \\
\hline Agriculture Land & 7 & 15 & 1294 & 3 & 17 & 188 & 145 & 1383 & $92.8 \%$ \\
\hline Lake & 0 & 0 & 0 & 276 & 0 & 0 & 0 & 276 & $100 \%$ \\
\hline Shrubland & 0 & 47 & 38 & 0 & 296 & 92 & 5 & 393 & $75.4 \%$ \\
\hline Urban buildings & 7 & 54 & 226 & 0 & 97 & 713 & 25 & 943 & $75.6 \%$ \\
\hline Total & 64 & 286 & 1437 & 312 & 383 & 872 & 590 & 4019 & \\
\hline Producer's accuracy & $82.8 \%$ & $89.7 \%$ & $90 \%$ & $\%$ & $77.3 \%$ & $81.8 \%$ & 87.3 & & \\
\hline
\end{tabular}

Overall accuracy $=84.7 \%$

Kappa Coefficient $=80$. 
Table 6. Confusion matrix of 2013 LULC classification.

\begin{tabular}{|c|c|c|c|c|c|c|c|c|c|}
\hline \multirow[b]{2}{*}{ Classification Data } & \multicolumn{8}{|c|}{ Reference Data } & \multirow{2}{*}{$\begin{array}{l}\text { User's } \\
\text { accuracy }\end{array}$} \\
\hline & Forest & Woodlot & $\begin{array}{l}\text { Agriculture } \\
\text { Land }\end{array}$ & Lake & Shrubland & $\begin{array}{l}\text { Urban buildings } \\
\text { and Settlements }\end{array}$ & $\begin{array}{l}\text { Bare } \\
\text { land }\end{array}$ & Total & \\
\hline Forest & 46 & 0 & 44 & 0 & 2 & 26 & 0 & 106 & $43.4 \%$ \\
\hline Woodlot & 3 & 54 & 20 & 0 & 7 & 7 & 0 & 59 & $91.5 \%$ \\
\hline Agriculture Land & 9 & 10 & 1746 & 9 & 80 & 136 & 141 & 1841 & $94.84 \%$ \\
\hline Lake & 0 & 0 & 0 & 278 & 0 & 0 & 0 & 278 & $100 \%$ \\
\hline Shrubland & 8 & 15 & 110 & 0 & 353 & 70 & 1 & 387 & $91.2 \%$ \\
\hline Urban buildings & 1 & 19 & 343 & 0 & 135 & 672 & 4 & 967 & $69.5 \%$ \\
\hline Bare land & 0 & 0 & 90 & 0 & 0 & 27 & 299 & 316 & $94.6 \%$ \\
\hline Total & 55 & 66 & 2057 & 312 & 407 & 729 & 345 & 4019 & \\
\hline Producer's accuracy & $83.6 \%$ & $81.8 \%$ & $84.88 \%$ & $89.1 \%$ & $86.7 \%$ & $92.2 \%$ & $86.7 \%$ & & \\
\hline
\end{tabular}

Overall accuracy $=85.8 \%$

Kappa Coefficient $=79.7 \%$

Table 7. Confusion matrix of 2018 LULC classification.

\begin{tabular}{|c|c|c|c|c|c|c|c|c|c|}
\hline \multirow[b]{2}{*}{ Classification data } & \multicolumn{8}{|c|}{ Reference Data } & \multirow{2}{*}{$\begin{array}{l}\text { User's } \\
\text { accuracy }\end{array}$} \\
\hline & Forest & Woodlot & Agriculture land & Lake & Shrub land & $\begin{array}{l}\text { Urban Buildings } \\
\text { and Settlements }\end{array}$ & $\begin{array}{l}\text { Bare } \\
\text { land }\end{array}$ & Total & \\
\hline Forest & 73 & 14 & 5 & 15 & 10 & 4 & 0 & 84 & $87 \%$ \\
\hline Woodlot & 3 & 213 & 67 & 4 & 19 & 52 & 0 & 227 & $93.8 \%$ \\
\hline Agriculture land & 6 & 72 & 1524 & 8 & 94 & 259 & 136 & 1608 & $94.7 \%$ \\
\hline Lake & 0 & 0 & 0 & 231 & 0 & 0 & 0 & 231 & $100 \%$ \\
\hline Shrubland & 14 & 28 & 67 & 15 & 247 & 62 & 2 & 259 & $95 \%$ \\
\hline Bare land & 0 & 3 & 115 & 0 & 3 & 18 & 297 & 329 & $90.3 \%$ \\
\hline Total & 77 & 325 & 1772 & 283 & 301 & 850 & 338 & 3961 & \\
\hline Producer's accuracy & $94.8 \%$ & $65.5 \%$ & $86 \%$ & $81.6 \%$ & $82 \%$ & $92 \%$ & $87.7 \%$ & & \\
\hline
\end{tabular}

Overall accuracy $=85 \%$

Kappa Coefficient $=78 \%$

\section{Conclusion}

Spatio-temporal forest cover change in the form of deforestation is significant environmental problem demonstrated in Lume district. The main findings of this study disclosed that, a resume increase in agriculture land and urban buildings and settlements at the expense of forests and shrub lands throughout investigated periods (1985-2018). From the analysed results, the extent of land use/land cover in general and forest cover change in particular was fundamentally changed between 1985 and 2018. Specifically dramatic expansion of urban buildings/settlements and awesome decline of shrub lands as well as forests were monitored in the district. The study demonstrated that, areal coverage of forests and shrub land were declined from time to time, only maximum areal share of forests and shrub land at starting of study period and minimum share was recorded at the end of study period. Throughout the investigation, steady net increasing rate of expansions observed for urban buildings/settlements and agriculture land annually with the respective high rate of population growth and urbanization whereas, the reverse for forest and shrub land

Hence, to protect the forest resources and shrub land from extra expenditure and to utilize these natural resources in sustainable basis, improved urban planning and design should be prepared and implemented by urban planners. The plan should be based on reducing the need for more urban land and promoting upward growth to reduce pressure from agriculture and shrub land is crucial. Alleviation of food crops demand from agricultural land is important by increasing the productivity of land through using agroforestry technologies, expanding integrated agriculture to all farmers and using of new agricultural inputs that facilitated by agricultural and irrigation sectors. Further studies is required by forestry researchers on suitable tree species production that can tolerate the chronic dry period and adopt the environment should be considered as a strategy to increase productivity of multipurpose trees and emphasize spatial coverage of forests and shrub lands.

\section{Acronyms}

$\begin{array}{ll}\text { AOI } & \text { Area of Interest } \\ \text { ETM+ } & \text { Enhanced Thematic Mapper Pus } \\ \text { GDP } & \text { Gross Domestic Production } \\ \text { LU/LC } & \text { Land Use/Land Cover } \\ \text { MOFED } & \text { Ministry of Finance and Economic Development } \\ \text { OLI } & \text { Operational Land Imager } \\ \text { QGIS } & \text { Quantum Geographic Information Science } \\ \text { ROI } & \text { Region of Interest } \\ \text { SCP } & \text { Semi-Automatic Classification Plugin } \\ \text { TIRS } & \text { Thermal Infrared Scanner } \\ \text { TM } & \text { Thematic Mapper }\end{array}$




\section{References}

[1] FAO, 2011. Economic and Social Significance of Forests for Africa's Sustainable Development. Nature \& Faune vol. 25.

[2] Rashid, B., Iqbal, J., 2018. Spatiotemporal Change Detection in Forest Cover Dynamics along Landslide Susceptible Region of Karakoram Highway, Pakistan. ISPRS Annals of the Photogrammetry, Remote Sensing and Spatial Information Sciences 4, 177-184. https://doi.org/10.5194/isprs-annals-IV3-177.

[3] Zewdie, W. and Csaplovies, E., 2015. Remote sensing based multi-temporal land cover classification and change detection in northwestern Ethiopia. European Journal of Remote Sensing, 48 (1), pp. 121-139.

[4] FAO, 2015. Global Forest Resource Assessment. Desk Reference.

[5] Halefom, A., Teshome, A., Sisay, E. and Ahmad, I., 2018. Dynamics of Land Use and Land Cover Change Using Remote Sensing and GIS: A Case Study of Debre Tabor Town, South Gondar, Ethiopia. Journal of Geographic Information System, 10 (02), p. 165.

[6] Lillesand, T., Kiefer, R. W. and Chipman, J., 2014. Remote sensing and image interpretation. John Wiley \& Sons K. Elissa, "Title of paper if known," unpublished.

[7] Tymków, P., 2009. Application of photogrammetric and remote sensing methods for identification of resistance coefficients of high water flow in river valleys. Monografie (Poland).

[8] Alemu, B., Garedew, E., Eshetu, Z. and Kassa, H., 2015. Land

use and land cover changes and associated driving forces in north western lowlands of Ethiopia. Int. Res. J. Agric. Sci. Soil Sci, 5 (1), pp. 28-44

[9] Molla, M. B., 2015. Land use/land cover dynamics in the central rift valley region of Ethiopia: Case of Arsi Negele District. African Journal of Agricultural Research, 10 (5), pp. 434-449.

[10] Meshesha, T. W., Tripathi, S. K. and Khare, D., 2016. Analyses of land use and land cover change dynamics using GIS and remote sensing during 1984 and 2015 in the Beressa Watershed Northern Central Highland of Ethiopia. Modeling Earth Systems and Environment, 2 (4), pp. 1-12.

[11] Hosonuma, N., Herold, M., De Sy, V., De Fries, R. S., Brockhaus, M., Verchot, L., Angelsen, A. and Romijn, E., 2012. An assessment of deforestation and forest degradation drivers in developing countries. Environmental Research Letters, 7 (4), p. 044009.

[12] Eshetu, A. A., 2014. Forest resource management systems in Ethiopia: Historical perspective. International Journal of Biodiversity and Conservation, 6 (2), pp. 121-131.

[13] Yismaw, A., Gedif, B., Addisu, S. and Zewudu, F., 2014. Forest cover change detection using remote sensing and GIS in Banja district, Amhara region, Ethiopia. International Journal of Environmental Monitoring and Analysis, 2 (6), p. 354.

[14] Tolosa, A. T., 2018. Evaluating the Dynamics of Land Use/Land Cover Change Using GIS and Remote Sensing Data in Case of Yewoll Watershed, Blue Nile Basin, Ethiopia.

[15] Lucas, I. F. J., Janssen, F. and van der Wel, F. J., 1994. Accuracy assessment of satellite derived land cover data: A review. Photogrammetric Engineering \& Remote Sensing, 60 (4), pp. 426-479. 